\title{
シクロオレフィンポリマーヘの平滑回路形成
}

\author{
渡辺 充広 ${ }^{*}$, 松井 貴一 ${ }^{* *}$, 杉本 将治 ${ }^{* * *}$, 本間 英夫 ${ }^{* * * *}$
}

\section{Smooth Circuit Formation on Cycloolefin Polymers}

Mitsuhiro WATANABE* ${ }^{*}$ Kiichi MATSUI**, Masaharu SUGIMOTO*,** and Hideo HONMA*,***

\author{
*株式会社関東学院大学表面工学研究所（２239-0806 神奈川県横須賀市池田町4-4-1） \\ **関東学院大学大学院（干 236-8501 神奈川県横浜市金沢区六浦東1-50-1) \\ ***関東学院大学工学部 († 236-8501 神奈川県横浜市金沢区六浦東 1-50-1) \\ * Kanto Gakuin University Surface Engineering Research Institute (4-4-1 Ikeda-cho, Yokosuka-shi, Kanagawa 239-0806) \\ ** Graduate School, Kanto Gakuin University (1-50-1 Mutsuura-Higashi, Kanazawa-ku, Yokohama-shi, Kanagawa 236-8501) \\ ***Faculty of Engineering, Kanto Gakuin University (1-50-1 Mutsuura-Higashi, Kanazawa-ku, Yokohama-shi, Kanagawa 236-8501)
}

\begin{abstract}
Recently, low dielectric material has been commonly used as printed circuit board material, to improve the performance and efficiency of electronic equipment. PTFE(Polytetrafluoroethylene) is one of the candidates for such Low-k material. Conventionally, a complicated etched surface has to be created by a strong etching media in order to achieve a good adhesion between the deposited metal and substrate. However, this complicated etched surface becomes a problem due to transmission loss through the skin effect. We therefore looked at a Cycloolefin Polymer (COP) that has an electric characteristic equal to PTFE. Return-to-zero (Rz) obtained a reformed surface with a low degree of roughness (about $1.0 \mu \mathrm{m}$ ) by irradiating the COP with ultraviolet light for 10 minutes. With the use of a hypophosphorous acid type bath for electroless $\mathrm{Cu}$ plating, peel strength was $0.8 \mathrm{kNm}^{-1}$. A circuit with a comb type pattern was formed by a subtractive process. An initial insulation resistance was measured on the comb type pattern (the width of the circuit and the interval of pattern were $50 \mu \mathrm{m})$ with $100 \mathrm{~V}$ impressed voltage and was shown to have a high enough value $\left(1.7 \times 10^{13} \Omega\right)$.
\end{abstract}

Key Words: Cycloolefin Polymers, Low-k Material, UV Irradiation

\section{1. 緒 言}

近年, 電子機器の高機能化 ·高性能化に伴い, 信号処理 速度の高速化が重要な課題の 1 つとなっている。通信分野 においては多くの情報を送受信するため, $\mathrm{GHz}$ 帯の高周波 が利用されている。一方，プリント配線板においては，信 号伝播速度の高速化・高周波化に対応するため, 配線板材 料の特性として低誘電率, 低誘電損失 (低 $\tan \delta$ ), 耐熱性 および低吸湿性などが求められている。このような特性を むつ代表的な材料としてフッ素材料であるポリテトラフル オロエチレン（以下，PTFE）が用いられている。この PTFEに導体層を形成する場合には，一般的に金属ナトリ ウムを用いた表面処理が行われている1)。しかしながら， この手法で得られた改質表面は非常に粗雑であり，めっき を成膜しても十分な密着性は得られにくい。さらに，この 処理においては洗浄などの工程で有機溶剤が必要となるた め，作業者や環境への悪影響が問題となる。
そこで，われわれはPTFE と同等な電気特性 (Table 1) $)^{2,3)}$ をもつシクロオレフィンポリマー（以下，COP）に着目し た。COPはシクロオレフィン類をモノマーとして合成され る主鎖に脂肪族環構造を有するポリマーである。工業的に は，シクロオレフィン類の中でも反応性に優れているノル ボルネン類が主に用いられている (Fig. 1)。ノルボルネン類 モノマーの重合反応としては，開環メタセシス重合 ${ }^{4)}$, 付 加重合および他のオレフィン類との付加共重合などが一般 的であり, 開環メ夕セシス重合によるポリマーおよび $\alpha$ オレフィンとの付加共重合によるポリマーが実用化されて (る5)。この材料へ導体層を形成する場合には，COPに粗 化処理を施した銅箔を熱プレスなどにより接着した後，銅 箔をエッチング加工して行う。もしくは，樹脂表面を強力 な酸化剤や有機溶媒などにより粗化処理後, 無電解めっ き，電気めっきなどにより導体層を形成する方法もある。 しかしながら，上述の処理法では樹脂表面の凹凸が大きい ため，表皮効果による伝送損失が問題となり，信号の高速 
Table 1. Characterization of COP and PTFE

\begin{tabular}{l|c|c}
\hline \multicolumn{1}{c|}{ Characterization } & COP & PTFE \\
\hline Specific gravity & 1.01 & $2.14 \sim 2.20$ \\
Water absorption $(\mathrm{wt} \%)$ & $<0.01$ & $<0.01$ \\
Deflection temperature $\left({ }^{\circ} \mathrm{C}\right)$ & 123 & 55 \\
$\quad$ under load & & \\
Coefficient of linear & $7.0 \times 10^{-5}$ & $10 \times 10^{-5}$ \\
$\quad$ expansion $\left(\mathrm{cm} / \mathrm{cm}^{\circ} \mathrm{C}\right)$ & & \\
Bending strength $\left(\mathrm{kgf} / \mathrm{cm}^{2}\right)$ & 960 & $3,500 \sim 6,300$ \\
Tensile elastic modulus $\left(\mathrm{kgf} / \mathrm{cm}^{2}\right)$ & 22,000 & $4,000 \sim 5,600$ \\
Tensile strength $\left(\mathrm{kgf} / \mathrm{cm}^{2}\right)$ & 600 & $140 \sim 350$ \\
Tensile stretch $(\%)$ & 40 & $200 \sim 400$ \\
Izod impact strength $(\mathrm{kgf} \cdot \mathrm{cm} / \mathrm{cm})$ & 2.4 & 16.3 \\
Volume resistivity $(\Omega \cdot \mathrm{cm})$ & $>10^{16}$ & $>10^{16}$ \\
Dielectric strength $(\mathrm{kV} / \mathrm{mm})$ & 40 & $9.0 \sim 12$ \\
Permittivity 【1.0 $\mathrm{GHz} 】$ & 2.3 & 2.2 \\
Dielectric dissipation factor 【1.0 GHz】 & $3.0 \times 10^{-4}$ & $2.0 \times 10^{-4}$ \\
\hline
\end{tabular}

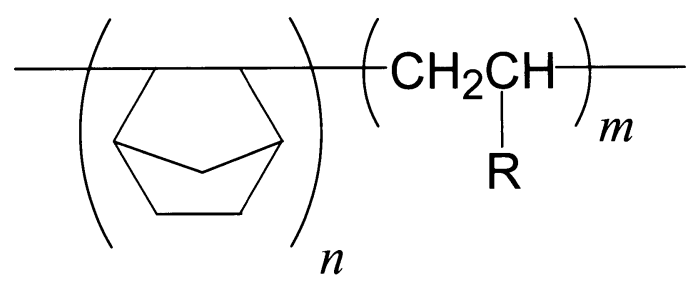

Fig. 1 Cycloolefin polymers

化や高周波化への対応は困難であると考えられる6。

本研究では，優れた誘電特性をむつCOPへの低粗度な表 面改質について検討を行い，その改質面へ銅めっきを施す ことで，平滑性に優れた導体層の形成技術を検討した。

\section{2. 実験方法}

\section{1 試験基板}

試験基板の COPには，日本ゼオン製を用い， $20 \mathrm{~mm} \times 50$ $\mathrm{mm} \times 3.0 \mathrm{mmt}$ に切り出した。切り出した基板は改質処理前

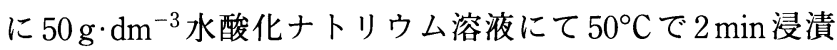
脱脂後, 十分に水洗し, 実験に供した。

\section{2 表面改質処理方法}

表面改質処理法として, 以下の 3 種類の方法で検討を 行った。

\subsection{1 プラズマ処理}

プラズマ処理は酸素流量 $2.5 \mathrm{dm}^{3} \cdot \mathrm{min}^{-1}$, 真空度 $3.3 \times$ $10^{-4} \mathrm{~Pa}$ 下で行った。なお，プラズマ装置には March Plasma Systems 社製 PWB-24を用いた。

2.2.2 UV 処理

大気下に扔いてUVランプ表面から試験基板表面までの 距離が $30 \mathrm{~mm}$ となるように UV 照射装置内で調節し，上部 よりUVを照射した（以下，UV処理）。UV装置には，高出 力低圧水銀灯（主波長 $253.7 \mathrm{~nm}$ ）を備えた PHOTO SURFACE PROCESSOR（セン特殊光源製 UVE-200J）を使用し
た。また，UV照射前にUV METER（浜松ホトニクス製， Model C6080-02）を用い，照射強度を測定し，約 9.0 10.0 $\mathrm{mW} \cdot \mathrm{cm}^{-2}$ で安定した状態であることを確認している。

2.2.3 $\mathrm{TiO}_{2}$ 改質処理 ${ }^{7)}$

試験基板をガラスシャーレに固定し，そこに超純水中に $10 \mathrm{mg} \cdot \mathrm{dm}^{-3}$ の酸化チタン（和光純薬工業製和光一級のア ナターゼ型）を超音波照射装置（本多電子製 $100 \mathrm{~W}$ ULTRASONIC MULTI CLEANER，型式：W-113）を用いて 28, 45 および $100 \mathrm{kHz}$ の周波数で各 5 秒間超音波洗浄を繰り返 し, 合計 $300 \mathrm{~s}$ 行い, 均一分散させた㲘濁溶液を試験基板 表面之液面までの距離が $4.5 \mathrm{~mm}$ になるように注入した。ま た，UVランプ表面から試験基板表面までの距離が $54 \mathrm{~mm}$ となるようにUV 照射装置内で調節し，上部よりUVを照 射した（以下， $\mathrm{TiO}_{2}$ 処理）。なお，ここで使用した UV 装 置には, 2.2 .2 項と同様の装置を使用し, 照躬強度も同様に 安定した状態であることを確認している。

\section{3 各種表面改質処理の評価}

各種表面改質処理の効果を確認するため, 改質表面に水 滴を滴下し，接触角から濡れ性を評価した。濡れ性の向上 が認められた試験基板について, 表面の官能基変化を確認 するため，赤外分光分析装置 (Perkin Elmer製 Auto IMAGE，以下顕微 IR）を用いて測定した。表面形態の観 察には走查型電子顕微鏡（日本電子データム製 JSM-5200, 以下SEM）を用いた。また，表面粗さおよび断面観察には 超深度形状測定顕微鏡（キーエンス製VK-8500, 以下レー ザ顕微鏡）を使用した。

\section{4 めっき皮膜評価方法}

各種改質処理後の試験基板に無電解銅めっきを用いて, 無電解銅めっきを約 $0.5 \mu \mathrm{m}$ ，続いて，電気銅めっきを約 $20 \mu \mathrm{m}$ 施し, 密着性評価をテープ試験もしくはピール試験 機で測定を行った。この密着強度測定はJIS 規格 C6481に 準拠し， $90^{\circ}$ ピール試験にて行った。無電解銅めっきには

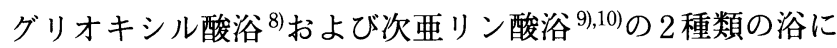
ついて検討を行った。

また，電気銅めっき浴には一般浴を用い，添加剤に萑原 ユージライト製のUBAC-Ep を用い，約 $20 \mu \mathrm{m}$ 厚付けした。

無電解銅めっき皮膜成膜後の密着性試験はテープ試験に より簡易的な試験を行い，剥離が見られなかった基板に対 して，銅めっき厚付け後，MKSハイピレス 精密力量測定 機（丸菱科学機械製作所製，型式：850242）を用いてピー ル強度を測定した。

\section{5 回路形成およびその評価方法}

2.4 項において，密着性およびはんだ而熱性評価の結果が 良好な試験基板に対し，サブトラクティブ法 ${ }^{11)} に て L / S=50$, 75 および $100 \mu \mathrm{m}$ のくし型パターンの回路形成を行った。回 路形成後, 初期の絶縁抵抗を超絶縁抵抗計 (YHP 製 4329A HIGH RESISTANCE METER）を用い，印加電圧 $100 \mathrm{~V} て ゙$ 測 定した。 


\section{3. 実験結果および考察}

\section{1 各種表面改質処理の効果}

2.2 項で示した各種表面改質処理後, 水滴試験により濡 れ性を評価した。その結果，すべての改質処理において濡 れ性の向上を確認し, 最も濡れ性が向上したのはUV処理 であった。

次に, 改質処理を行った各種試験基板について, FT-IR による表面分析の結果を Fig. 2 に示す。実線が未処理，点 線がプラズマ処理 $30 \mathrm{~min}$, 一点鎖線が UV 処理 $30 \mathrm{~min}$ お び破線が $\mathrm{TiO}_{2}$ 処理 $30 \mathrm{~min}$ である。その結果，プラズマ処理 では, 吸収の増減は認められなかった。一方, UV 処理お よび $\mathrm{TiO}_{2}$ 処理においては, $3,445 \mathrm{~cm}^{-1}$ 付近に- $\mathrm{OH}$ 基に起因 する吸収および $1,714 \mathrm{~cm}^{-1}$ 付近に $-\mathrm{C}=\mathrm{O}$ 基に起因する吸収 の増加が確認できた。また， $2,900 \mathrm{~cm}^{-1}$ 付近に見られる $\mathrm{C}-\mathrm{H}$ 結合に起因する吸収の減少が確認できた。さらに, UV 処 理および $\mathrm{TiO}_{2}$ 処理を比較すると, 前者の方が吸収の増減が 大きく, 前述の結果と同様に改質効果が高いことがわかっ た。

以上のことから，プラズマ処理における濡れ性の向上は, 吸収の増減が見られないことから，表面の清浄化によるも のと考えられる。一方，UV処理および $\mathrm{TiO}_{2}$ 処理において は, UVがCOP分子構造中の C-Hに作用し, 結合が切断さ れ，新たに一 $\mathrm{OH}$ 基が形成されたためと考えられる。

次に，改質処理前後の表面SEM 像をFig. 3 に示す。a)が 未処理, b) がプラズマ処理 $30 \mathrm{~min}$, c) が UV 処理 $30 \mathrm{~min}$ お よび d) が $\mathrm{TiO}_{2}$ 処理 $30 \mathrm{~min}$ である。その結果, UV 処理 $30 \mathrm{~min} に$ にいて, 表面に直径 $3.0 \mu \mathrm{m}$ 以下の微細孔の形成が 確認できる (Fig. 3c)。これは，上述のIRの結果と同様に， COPにUVが作用することで, 分子の一部の結合が切断さ れ，新たな官能基が発現すると同時に，構造の分解も進行 することで生じた微細孔であると考えられる。一方, $\mathrm{TiO}_{2}$ 処理においては水中でUV照射しているため, UV が減衰 し，試験基板表面に到達するUV光量が少ないため，UVに よる改質効果が少なくなったと考えられる。さらに, $\mathrm{TiO}_{2}$ が励起することでラジカル種が生成するが，COPにおいて は効果がないものと考えられる。

また, 改質処理前後の十点平均粗さ $(\mathrm{Rz})$ は末処理, プラ ズマ処理 $30 \mathrm{~min}, \mathrm{UV}$ 処理 $30 \mathrm{~min}$ および $\mathrm{TiO}_{2}$ 処理 $30 \mathrm{~min}$ に

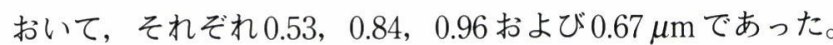
粗化処理を施した銅箔の $\mathrm{Rz}$ は $5.0 \sim 7.0 \mu \mathrm{m}$ 程度であるため, 本処理法は非常に低粗化であることがわかる。

\section{2 密着性の評価}

まず，グリオキシル酸浴を用いて約 $0.5 \mu \mathrm{m}$ 成膜した各種 改質処理基板のテープ試験を行った。その結果, プラズマ 処理および $\mathrm{TiO}_{2}$ 処理ではテープ試験において剥離を生じ た。一方, UV 処理では剥離を生じなかった。

次に，テープ試験に抽いて剥離が認められなかったUV

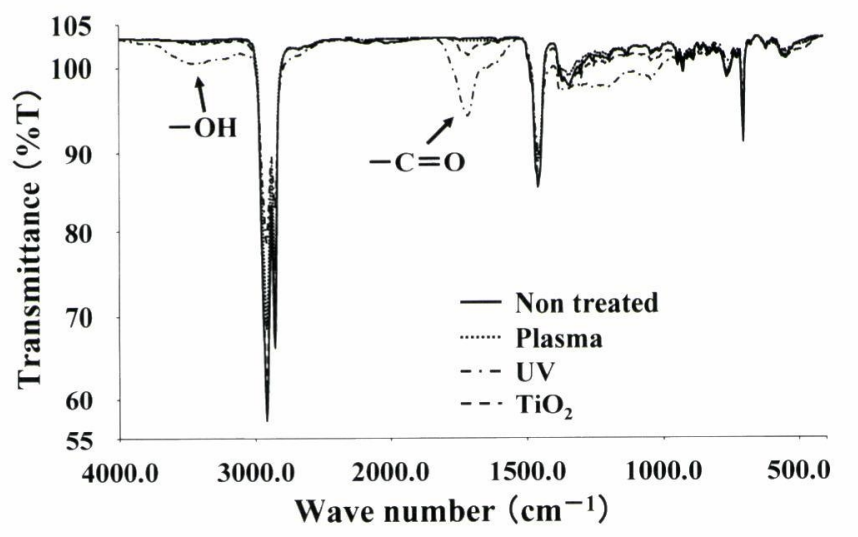

Fig. 2 IR spectrum of COP with several treatments
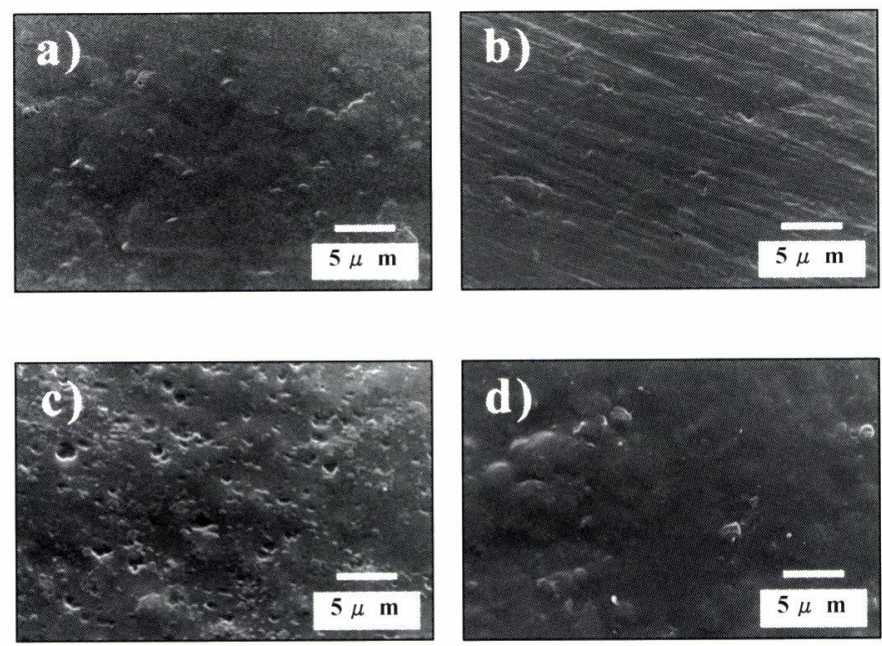

Fig. 3 SEM images of surface morphology of a) Non treated b) Plasma treatment c) UV treatment and d) $\mathrm{TiO}_{2}$ treatment

処理に対して，ピール試験機を用いて測定を行った結果， ピール強度は $0.53 \mathrm{kNm}^{-1}$ であった。さらに, 無電解銅めっ き浴を次亜リン酸浴に変更してめっきを施し, ピール試験 を行った結果, ピール強度は $0.68 \mathrm{kNm}^{-1}$ であった。

以上の結果, 最もピール強度が高かった改質処理法は UV 処理であった。また, 無電解銅めっき浴においては, ピール強度からグリオキシル酸浴よりも次亜リン酸浴が有 効であることを確認した。

ここで, グリオキシル酸浴と次亜リン酸浴でピール強度 に差が認められたことは, 銅の析出速度と析出形態の違い によるもの上考えられる。つまり, 次亜リン酸浴はグリオ キシル酸浴と比較して銅の析出速度が $1 / 2$ と遅いため, めっ き液が樹脂の改質面に浸透しやすく, 樹脂と良好な密着強 度が得られたものと考えられる。また，析出形態について はグリオキシル酸浴から析出した銅は岩盤状でフラットな めっき膜に対して ${ }^{8)}$, 次亜リン酸浴から析出した銅は針状 となる ${ }^{9), 10)}$ 。こため, 次覀リン酸浴では電気銅めっき皮 膜とアンカー効果により密着し, 高いピール強度が得られ たものと考えられる。確認のため, グリオキシル酸浴およ 
び次亜リン酸浴を用いたときの銅めっき皮膜の抵抗值を測 定したが，それぞれ $10.2 \mathrm{~m} \Omega$ および $10.4 \mathrm{~m} \Omega$ とほとんど差が なかった。

次に，最適条件を検討するために，UV処理において， UV 照射時間を $10,20,30$ および $45 \mathrm{~min}$ と変化させた。各処 理時間における Rz はそれぞれ $0.51,0.72,0.96$ および $0.89 \mu \mathrm{m}$ であった。UV照射後, 無電解銅めっき浴に次曲リン酸浴 を用いて約 $0.5 \mu \mathrm{m}$ 成膜し, 続いて電気銅めっきで約 $20 \mu \mathrm{m}$ 厚付けし，ピール試験機を用いて測定を行った。その結果， 各処理時間におけるピール強度はそれぞれ $0.79,0.80,0.68$ お よび $0.61 \mathrm{kNm}^{-1}$ であった。

以上の結果, COPの最適改質処理条件は, UV 処理 10〜20 minであることがわかった。また，表面粗さとピー ル強度に相関性はない上考えられる。

次に, 最適条件におけるピール試験後の樹脂面の SEM 像 をFig. 4 に示す。その結果, 粗化処理後の表面SEM像 (Fig. 3c) では $3.0 \mu \mathrm{m}$ 以下の微細孔の形成が確認できたのに対し, ピール試験後の樹脂面では, 直径 $5.0 \sim 10.0 \mu \mathrm{m}$ 程度の微細 孔が多数確認できる。このことは, 樹脂が銅皮膜に強く密 着していたため，銅とともに引き剥がされたと考えられる。

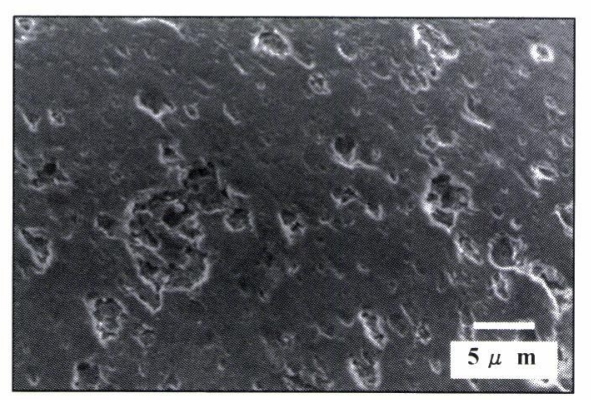

Fig. 4 SEM image of COP surface after peeling test for optimum condition

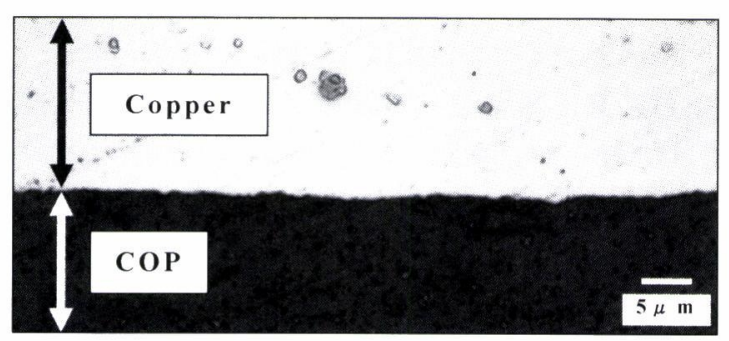

Fig. 5 Cross-sectional laser microscope image of surface morphology by UV treatment
以上のことから, 破壊モードは樹脂の凝集破壊であること を確認した。また，めっき後の断面をレーザ顕微鏡により 観察した結果をFig. 5 に示す。その結果, 試験基板とめっ き皮膜の界面には $1.0 \mu \mathrm{m}$ 程度の凹凸しか見られず, 非常に 平滑であることが確認された。

\section{3 回路形成およびその評価}

最適条件下で改質処理および銅めっきを成膜した試験基 板にサブトラクティブ法にて $\mathrm{L} / \mathrm{S}=50,75$ および $100 \mu \mathrm{m} の く$ し型パターンの回路形成を行った(Fig. 6)。一連の回路加工 工程において, 剥離や外観異常などの不具合は認められな かった。くし型パターンの回路を用いて, 初期の絶縁抵抗 を測定した結果, $\mathrm{L} / \mathrm{S}=50 \mu \mathrm{m}$ において, 印加電圧 $100 \mathrm{~V}$ 測 定で $1.7 \times 10^{13} \Omega$ と十分な初期抵抗值を示した。

\section{4. 結言}

本手法は, $\mathrm{COP}$ へ平滑な回路形成を行うために, 低粗度 な表面改質法を検討した。その結果, 最適条件下でUV処 理を行うことで, 平滑性に優れた導体層の形成が可能と なった。また，強力な酸化剂などを一切用いることなく， UVにより表面改質を行うため，環境配慮型の前処理であ る。COPはPTFE と同等の電気特性を有するため, PTFE の代替配線板材料として利用可能であると考えられる。

\section{謝 辞}

本研究は文部科学省ハイテク・リサーチ・センター整備 事業（平成 17 年度〜平成 22 年度）による私学助成を得て 行われた。

(2006.12.14-受理)

\section{文献}

1) 豊永 実: “プリント配線板のめっき技術”, 槙書店, 1999, p. 95

2) 小原禎二：“非晶質シクロオレフィンポリマー”

3) 小原禎二：“光学プラスチック用シクロオレフィンポリ マー”, 日本ゴム協会誌, Vol. 79, No. 4, p. 244, 2006

4) 新版高分子大辞典, 朝倉書店, 第6 版, p. 455

5) 小林 正：“プリント板と実装技術”, 日刊工業新聞社, 2005, p. 37

6) “ZEONEX”，日本ゼオン, 2005, p. 13

7) 杉本将治, 田代雄彦, 別所 毅, 小岩一郎, 本間英夫：
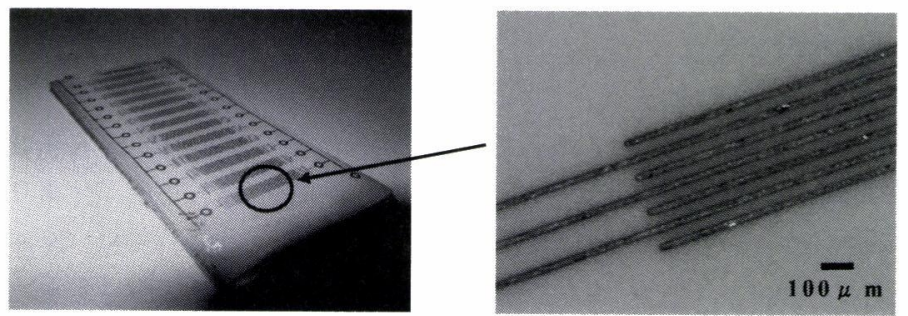

Fig. 6 Test sample for insulation resistance measurement 
“UV および $\mathrm{TiO}_{2}$ を用いた $\mathrm{ABS}$ 樹脂の改質効果”，表面技 術, Vol. 57, p. 162, 2006

8) J. Darken: Printed Circuit World Convention, Vol. 5, pp. 12-15, 1990

9) 本間英夫，藤波知之：“次亜リン酸を還元剂とする無電解 銅めっきによる内層銅箔処理”, プリント回路学会誌「サー
キットテクノロジ」, Vol. 6, p. 209, 1991

10）渡辺充広：“無電解めっき法によるハローレス内層処理”, 表面実装技術, 日刊工業新聞社, 1992, p. 19

11）藤平正気, 藤森秀信 : “多層プリント配線板ステップ $365 ”$, 工業調査会, 2003, p. 194 